\title{
Does taking probiotics routinely with antibiotics prevent antibiotic associated diarrhoea?
}

\author{
Christopher C Butler professor of primary care medicine, Donna Duncan senior project manager, \\ Kerenza Hood professor of statistics \\ Cardiff University, Cardiff CF14 4XN, UK
}

This is one of a series of occasional articles that highlight areas of practice where management lacks convincing supporting evidence. The series adviser is David Tovey, editor in chief, the Cochrane Library. This paper is based on a research priority identified and commissioned by the National Institute for Health Research's Health Technology Assessment programme on an important clinical uncertainty. To suggest a topic for this series, please email us at uncertainties@bmj.com

Diarrhoea develops in association with antibiotic treatment in $1 \%$ to $44 \%^{12}$ of cases, and ranges from mild episodes that resolve when antibiotics are stopped to serious complications such as toxic megacolon, bowel perforation, and death. Risk is increased with extremes of age, co-morbidity, oral broad spectrum antibiotics (particularly clindamycin, $\beta$-lactams, and third generation cephalosporins), prolonged antibiotic duration, previous antibiotic associated diarrhoea, and hospitalisation. Probiotics-live microorganisms that, when administered in adequate amounts, confer a health benefit on the host-are present in products available in shops as foodstuffs, and in formulations used for specific therapeutic purposes. Probiotics are thought to combat antibiotic associated diarrhoea through restoring resistance to colonisation by pathogenic bacteria after the normal colonic microflora have been damaged by antibiotics, by breaking down non-absorbable compounds into absorbable products, by interfering with pathogenic toxins, and by enhancing immunity. Effects of probiotics vary by strain owing to differing resistance to gastric acid and bile, ability to colonise mucosa, and susceptibility to antibiotics. ${ }^{3}$

Probiotics carry theoretical risks, including infection beyond the gut and transfer of antibiotic resistant genes. However, so far, there have been no reports of bacteraemia or fungaemia attributable to the probiotics in trials included in published systematic reviews. ${ }^{4-10}$

Lactobacillus bacteraemia is rare and has a low mortality rate. ${ }^{11}$ Cancer, diabetes, broad spectrum antibiotic therapy, organ transplantation, and abscess may be risk factors for lactobacillus bacteraemia. Twelve cases of lactobacillus bacteraemia have been reported in patients taking a probiotic and 24 cases of fungaemia associated with the probiotic Saccharomyces boulardii. However, many lactobacillus strains are human commensals and a review identified only five well documented published cases where the consumed probiotic strain was the same as a clinical isolate. ${ }^{11}$ Mild to moderate gastrointestinal side effects and rash are generally no more common than in patients on placebo probiotic. ${ }^{6}$

Probiotics may therefore be an attractive option for preventing antibiotic associated diarrhoea because they are cheap (the cost of preventing one case in selected hospital patients may be as low as $£ 50 ; € 60, \$ 79)^{12}$ and safe.

\section{What is the evidence of uncertainty?}

We conducted a review of meta-analyses, updated with subsequent randomised controlled trials. We searched PubMed, EMBASE, the Cochrane Library, and Clinical Evidence in October 2011 for meta-analyses published in the past five years in English and trials published after their search dates on probiotics to prevent antibiotic associated diarrhoea using the search terms "probiotic" and "antibiotic associated diarrhoea [or diarrhea]". We excluded prevention studies, small pilot studies, studies that were not placebo controlled, studies published only in abstract form, studies focusing on antibiotic associated diarrhoea caused by a single organism (such as Clostridium difficile), and systematic reviews without meta-analysis.

The commonest outcome measure was diarrhoea, defined as three loose stools in a 24 hour or 48 hour period. $\Downarrow$ The type of probiotic tested, study populations, and effect sizes varied widely between studies, with both statistically significant ${ }^{2}$ and non-significant ${ }^{1314}$ findings for the primary outcome and widely differing rates of antibiotic associated diarrhoea. Many of the trials identified in the systematic reviews were of poor quality. ${ }^{6}{ }^{18}$ Reasons included poor allocation concealment, inadequate power, possible publication bias, variation in outcome measures, lack of intention to treat analyses, variation in follow-up duration, lack of cost-benefit data, variation in illness severity, and the small proportion of eligible patients 
enrolled. We found no head to head comparisons of probiotic strains.

\section{Is ongoing research likely to provide relevant evidence?}

We searched the Current Controlled Trials database (www. controlled-trials.com) for ongoing randomised controlled trials using the previously described search terms. Six placebo controlled trials are in progress examining the effect of probiotics in preventing antibiotic associated diarrhoea in hospitalised patients. Three (ISRCTN57305201,

ISRCTN10768531, and isrctn19604441) are investigating the effect of a mixed probiotic, VSL\#3, containing eight species of bacteria licensed for use in irritable bowel syndrome, with one recruiting exclusively from intensive care units

(ISRCTN10768531). One trial (NCT01087892) is investigating the effect of Actimel, which contains three species (Lactobacillus casei DN 114 001, Lactobacillus bulgaricus, and Streptococcus thermophilus) and one (ISRCTN70017204) is investigating the effect of a probiotic that contains two strains of Lactobacillus acidophilus (National Collection of Industrial, Food and Marine Bacteria (NCIMB) 30157 and 30156), Bifidobacterium bifidum (NCIMB 30153) and Bifidobacterium lactis (NCIMB 30172). One (ISRCTN86623192) is investigating the effect of $S$ boulardii. These studies will provide information on probiotics to prevent antibiotic associated diarrhoea in a wider range of hospitalised patients and may be large enough to provide information on which subgroups of patients are at greatest risk and are most likely to benefit.

No randomised controlled trials have specifically assessed the use of probiotics with antibiotics in care homes. Robust data are lacking on levels of antibiotic use and on frequency and severity of associated diarrhoea this setting. Our Probiotics for Antibiotic Associated Diarrhoea (PAAD) Study

(ISRCTN79548440) is in an observational phase to determine whether a trial of probiotics to prevent antibiotic associated diarrhoea is justified and feasible in care homes.

There is an absence or insufficiency of high quality evidence to support routine use of probiotics to prevent antibiotic associated diarrhoea in all people, regardless of age, comorbidity, and care setting. For example, few trials have been done in primary care, ${ }^{9}$ and we found none from intermediate and social care settings. We found no pragmatic, open implementation studies.

\section{What should we do in the light of uncertainty?}

Good evidence exists to support using probiotics with $S$ boulardii and Lactococcus rhamnosus GG (ATCC 53103) ${ }^{5} 67$ to prevent antibiotic associated diarrhoea, with emerging evidence for certain mixed strains that include $L$ casei or $L$ acidophilus. ${ }^{10}$ Probiotics also seem to be more effective at higher doses. ${ }^{268}$ However, because insufficient evidence exists to support routinely using probiotics for this purpose, and because of the low incidence and generally mild severity of antibiotic associated diarrhoea in otherwise healthy people, we recommend against routine use of probiotics in all people taking antibiotics to prevent antibiotic associated diarrhoea. Not all probiotics evaluated as part of clinical trials are commercially available in the United Kingdom. Nevertheless, probiotics are cheap and safe, so routine use with antibiotics is justified in frail patients in hospital and possibly in children. Those who have previously had antibiotic associated diarrhoea should be offered probiotics when they are treated with antibiotics, regardless of setting, but probiotics should be avoided in people who are seriously immunocompromised. As probiotics seem more effective at higher doses, ${ }^{268}$ doses of at least 50 billion colony forming units should be used; probiotics should be taken for the duration of antibiotic treatment and continued for a week thereafter.

Evidence about the effectiveness of many strains is absent or insufficient. Head to head studies of probiotic strains are needed, as well as more studies to identify groups of patients at greatest risk and most likely to benefit, especially in the community and in intermediate care.

Contributors: $\mathrm{DD}$ and $\mathrm{CB}$ developed and conducted the searches and drafted the paper, which was revised by $\mathrm{CB}, \mathrm{DD}$, and KH. CB is guarantor.

Competing interests: All authors have completed the Unified Competing Interest form at www.icmje.org/coi_disclosure.pdf (available on request from the corresponding author) and declare: no support from any organisation for the submitted work; The HTA has funded research involving probiotics for which all authors are grant holders; no other relationships or activities that could appear to have influenced the submitted work.

Provenance and peer review: Commissioned; externally peer reviewed.

1. Wistrom J, Norrby SR, Myhre EB, Eriksson S, Granstrom G, Lagergren L, et al. Frequency of antibiotic-associated diarrhoea in 2462 antibiotic-treated hospitalized patients: a prospective study. J Antimicrob Chemother 2001;47:43-50.

2 Gao XW, Mubasher M, Fang CY, Reifer C, Miller LE. Dose-response efficacy of a proprietary probiotic formula of Lactobacillus acidophilus CL1285 and Lactobacillus casei LBC80R for antibiotic-associated diarrhea and Clostridium difficile -associated diarrhea prophylaxis in adult patients. Am Jour Gastroenterol 2010;105:1636-41.

3 Hickson M. Probiotics in the prevention of antibiotic-associated diarrhoea and Clostridium difficile infection. Ther Adv Gastroenterol 2011;4:185-97.

4 Szajewska H, Ruszczynski M, Radzikowski A. Probiotics in the prevention of antibiotic-associated diarrhea in children: a meta-analysis of randomized controlled trials. J Pediatr 2006;149:367-72.

5 McFarland LV. Systematic review and meta-analysis of Saccharomyces boulardii in adult patients. World J Gastroenterol 2010;16:2202-22.

6 McFarland LV. Meta-analysis of probiotics for the prevention of antibiotic associated diarrhea and the treatment of Clostridium difficile disease. Am J Gastroenterol 2006;101:812-22.

7 Kale-Pradhan PB, Jassal HK, Wilhelm SM. Role of lactobacillus in the prevention of antibiotic-associated diarrhea: a meta-analysis. Pharmacotherapy 2010;30:119-26.

8 Johnston BC, Supina AL, Ospina M, Vohra S. Probiotics for the prevention of pediatric antibiotic-associated diarrhea. Cochrane Database Syst Rev 2007;2:CD004827.

9 Sazawal S, Hiremath G, Dhingra U, Malik P, Deb S, Black RE. Efficacy of probiotics in prevention of acute diarrhoea: a meta-analysis of masked, randomised, placebo-controlled trials. Lancet Infect Dis 2006;6:374-82.

10 Avadhani A, Miley H. Probiotics for prevention of antibiotic-associated diarrhea and Clostridium difficile -associated disease in hospitalised adults-a meta-analysis. J Am Acad Nurse Practitioners 2011;00:1-6.

11 Liong MT. Safety of probiotics: translocation and infection. Nutr Rev 2008;66:192-202.

12 Hickson M, D'Souza AL, Muthu N, Rogers TR, Want S, Rajkumar C, et al. Use of probiotic Lactobacillus preparation to prevent diarrhoea associated with antibiotics: randomised double blind placebo controlled trial. BMJ 2007:335:80-3.

13 Lonnermark E, Friman V, Lappas G, Sandberg T, Berggren A, Adlerberth I. Intake of Lactobacillus plantarum reduces certain gastrointestinal symptoms during treatment with antibiotics. J Clin Gastroenterol 2010;44:106-12

14 Song HJ, Kim JY, Jung SA, Kim SE, Park HS, Jeong Y, et al. Effect of probiotic lactobacillus (Lacidofil (R) Cap) for the prevention of antibiotic-associated diarrhea: a prospective, randomized, double-blind, multicenter study. J Korean Med Sci 2010;25:1784-91.

15 Psaradellis E, Sampalis J. Efficacy of BIO K+ CL1285 in the reduction of antibiotic associated diarrhea - a placebo controlled, multicenter study. Arch Med Sci 2010;6:56-64.

16 Merenstein DJ, Foster J, D'Amico F. A randomized clinical trial measuring the influence of kefir on antibiotic-associated diarrhea: the measuring the influence of Kefir (MILK) Study. Arch Pediatr Adolesc Med 2009;163:750-4.

17 Szymanski H, Armanska M, Kowalska-Duplaga K, Szajewska H. Bifidobacterium longum PL03, Lactobacillus rhamnosus KL53A, and Lactobacillus plantarum PL02 in the prevention of antibiotic-associated diarrhea in children: a randomized controlled pilot trial. Digestion 2008;78:13-7.

18 Katz JA. Should probiotics be routine therapy for the prevention of antibiotic-associated diarrhea? J Clin Gastroenterol 2010;44:83-4.

Accepted: 27 October 2011

Cite this as: BMJ 2012;344:e682

(c) BMJ Publishing Group Ltd 2012 


\section{Table}

Table 1| Systematic reviews of randomised placebo controlled trials (RCTs) and subsequent individual trials of probiotics to prevent antibiotic associated diarrhoea

\begin{tabular}{|c|c|c|c|}
\hline $\begin{array}{l}\text { Reference } \\
\text { (search date) }\end{array}$ & $\begin{array}{l}\text { Number of studies and/or total number } \\
\text { of participants, care setting }\end{array}$ & $\begin{array}{l}\text { Intervention: organism in probiotic and } \\
\text { daily dose (colony forming units) }\end{array}$ & $\begin{array}{l}\text { Outcome (risk ratio) for antibiotic } \\
\text { associated diarrhoea }\end{array}$ \\
\hline \multicolumn{4}{|l|}{ Systematic reviews } \\
\hline $\begin{array}{l}\text { McFarland } 2010^{5} \\
(1976-2009)\end{array}$ & $\begin{array}{l}10 \text { RCTs, } 1858 \text { adults, } 4 \text { trials in } \\
\text { hospitalised patients, } 1 \text { outpatient, } 3 \text { in } \\
\text { patients receiving antibiotic treatment for } \\
H \text { pylori infection }\end{array}$ & $S$ boulardii, ranging from $4 \times 10^{9}$ to $2 \times 10^{10}$ & $0.47(95 \% \mathrm{Cl} 0.35$ to 0.63$)$ \\
\hline $\begin{array}{l}\text { Avadhani } 2010^{10} \\
\text { (unclear) }\end{array}$ & 8 RCTs, 1220 adults, inpatients & $\begin{array}{l}3 \text { trials of } S \text { boulardii, } 1 \text { of } L \text { rhamnosus, } 4 \text { of } \\
\text { mixed strains that included } L \text { casei, } L \\
\text { acidophilus, } L \text { bulgaricus, } S \text { thermophilus, } B \\
\text { bifidum, and } L \text { rhamnosus, range of doses }\end{array}$ & $0.56(95 \% \mathrm{Cl} 0.44$ to 0.71$)$ \\
\hline $\begin{array}{l}\text { McFarland } 2006^{6} \\
(1977-2005)\end{array}$ & $\begin{array}{l}25 \mathrm{RCTs}, 2810 \text { children and adults, } \\
\text { inpatients and outpatients including } H \\
\text { pylori treatment }\end{array}$ & $\begin{array}{l}6 \text { trials } S \text { boulardii, } 6 \text { trials } L \text { rhamnosus, } 6 \\
\text { other single strains, and } 7 \text { mixed strains, } \\
\text { ranging from } 1 \times 10^{7} \text { to } 1 \times 10^{11} \text { (mean dose } \\
3 \times 10^{9} \text { ) }\end{array}$ & $\begin{array}{l}\text { Combined } 0.43(95 \% \mathrm{Cl} 0.31 \text { to } 0.58) ; \\
\text { S boulardii } 0.37(95 \% \mathrm{Cl} 0.26 \text { to } 0.52) ; \\
\text { L rhamnosus } 0.31(95 \% \mathrm{Cl} 0.13 \text { to } 0.72)\end{array}$ \\
\hline $\begin{array}{l}\text { Kale-Pradham } 2010^{7} \\
\text { (inception -May 2008) }\end{array}$ & $\begin{array}{l}10 \text { RCTs, } 1862 \text { children and adults, } \\
\text { inpatients and outpatients }\end{array}$ & $\begin{array}{l}\text { Single agent lactobacillus, ranging from } 2 \times 109 \\
\text { to } 4 \times 10^{10}\end{array}$ & $\begin{array}{l}\text { Combined } 0.35 \text { (95\% Cl } 0.19 \text { to } 0.67) \\
\text { adults } 0.24 \text { ( } 95 \% \mathrm{Cl} 0.08 \text { to } 0.75) \\
\text { children } 0.44 \text { ( } 95 \% \mathrm{Cl} 0.18 \text { to } 1.08)\end{array}$ \\
\hline $\begin{array}{l}\text { Sazawal } 2006^{9} \text { (inception } \\
\text {-February 2006) }\end{array}$ & $\begin{array}{l}19 \text { RCTs, children and adults, inpatients } \\
\text { and outpatients }\end{array}$ & $\begin{array}{l}\text { Single ( } 5 \text { L rhamnosus) and mixed, ranging } \\
\text { from } 1 \times 7^{10} \text { to } 1 \times 10^{10}\end{array}$ & $0.48(95 \%$ C1 0.35 to 0.65$)$ \\
\hline $\begin{array}{l}\text { Szajewska } 2006^{4} \\
\text { (1966-December 2005) }\end{array}$ & $\begin{array}{l}6 \text { RCTs, } 766 \text { children, inpatients and } \\
\text { outpatients }\end{array}$ & $\begin{array}{l}2 \text { RCTs lactobacillus GG, one } S \text { boulardii, } 3 \\
\text { mixed, dose range unclear }\end{array}$ & $0.44(95 \% \mathrm{Cl} 0.25$ to 0.77$)$ \\
\hline $\begin{array}{l}\text { Johnston } 2007^{8} \\
\text { (inception to August } \\
\text { 2006) }\end{array}$ & $\begin{array}{l}9 \text { RCTs, } 1946 \text { children, inpatients and } \\
\text { outpatients }\end{array}$ & $\begin{array}{l}6 \text { single, } 3 \text { mixed containing (alone or in } \\
\text { combination) Lactobacillus spp, } \\
\text { Bifidobacterium spp, Streptococcus spp, } S \\
\text { boulardii, ranging from } 8.25 \times 10^{6} \text { to } 4 \times 10^{10}\end{array}$ & $\begin{array}{l}\text { Per-protocol analysis } 0.49 \text { ( } 95 \% \mathrm{Cl} 0.32 \text { to } \\
0.74) \text {; intention to treat analysis } 0.90(95 \% \mathrm{Cl} \\
0.50 \text { to } 1.63) ; 5 \text { studies of higher dose ( } 5 \text { to } 40 \\
\times 10^{9} \text { day) } 0.35(95 \% \mathrm{Cl} 0.25 \text { to } 47) ; 3 \text { studies } \\
\text { of low dose }\left(<5 \times 10^{9} \text { day) } 0.89(95 \% \mathrm{Cl} 0.53 \text {, }\right. \\
1.48)\end{array}$ \\
\hline
\end{tabular}

\section{Randomised controlled trials published after search dates of systematic reviews}

\begin{tabular}{|c|c|c|c|}
\hline Gao $2010^{2}$ & $\begin{array}{l}255 \text { adults, inpatients, } \\
744 \text { of } 1120 \text { ( } 66.5 \%) \text { eligible participants } \\
\text { were not recruited }\end{array}$ & $\begin{array}{l}\text { Combination of } L \text { acidophilus and } L \text { casei in } \\
\text { low }\left(5 \times 10^{9}\right) \text { or high }\left(10 \times 10^{9}\right) \text { dose }\end{array}$ & $\begin{array}{l}\text { High dose } 0.34 \text { ( } 95 \% \mathrm{Cl} 0.20 \text { to } 0.60) \\
\text { Low dose } 0.64 \text { ( } 95 \% \mathrm{Cl} 0.42 \text { to } 0.97) ; 15.5 \% \\
\text { low dose, } 28.2 \% \text { high dose intervention, and } \\
44.1 \% \text { placebo treated patients developed } \\
\text { diarrhoea }\end{array}$ \\
\hline Lonnermark $2010^{13}$ & $\begin{array}{l}239 \text { adults, inpatients and outpatients in a } \\
\text { university hospital infectious diseases clinic }\end{array}$ & $L$ plantarum, $1 \times 10^{10}$ & $\begin{array}{l}1.25(95 \% \mathrm{Cl} 0.40 \text { to } 3.92) ; 7.5 \% \text { intervention } \\
\text { and } 6.0 \% \text { treated placebo patients developed } \\
\text { diarrhoea }\end{array}$ \\
\hline Song $2010^{14}$ & $\begin{array}{l}214 \text { adults, inpatients, } 10 \text { tertiary hospitals } \\
\text { treated for a range of respiratory tract } \\
\text { infections (mostly pneumonia) }\end{array}$ & $L$ rhamnosus and $L$ acidophilus, $2 \times 10^{9}$ & $\begin{array}{l}0.54(95 \% \mathrm{Cl} 0.17 \text { to } 1.74) ; 3.9 \% \text { intervention } \\
\text { and } 7.2 \% \text { placebo treated patients developed } \\
\text { diarrhoea }\end{array}$ \\
\hline Psaradellis $2010^{15}$ & $\begin{array}{l}437 \text { adults, treated for a minimum of } 12 \\
\text { hours in a hospital ward or emergency } \\
\text { room in } 8 \text { centres }\end{array}$ & $L$ acidophilus and $L$ casei, $5 \times 10^{10}$ & $\begin{array}{l}0.74(95 \% \mathrm{Cl} 0.53 \text { to } 1.02) ; 21.8 \% \text { intervention } \\
\text { and } 29.4 \% \text { placebo treated patients developed } \\
\text { diarrhoea }\end{array}$ \\
\hline Merenstein $2009^{16}$ & $\begin{array}{l}125 \text { children with upper respiratory tract } \\
\text { infections aged } 1-5 \text {, in primary care }\end{array}$ & $\begin{array}{l}\text { Kefir fermented milk from grains containing } \\
\text { Lactococcus lactis, Lactococcus plantarum, } \\
\text { Lactococcus rhamnosus, Lactococcus casei, } \\
\text { Lactococcus lactis subspecies diacetylactis, } \\
\text { Leuconostoc cremoris, Bifidobacterium longum, } \\
\text { Bifidobacterium breve, Lactobacillus } \\
\text { acidophilus, and Saccharomyces florentinus; } \\
\text { doses of organisms not given }\end{array}$ & $\begin{array}{l}0.82(95 \% \mathrm{Cl}, 0.54 \text { to } 1.43) ; 18.0 \% \text { intervention } \\
\text { and } 21.9 \% \text { placebo treated children developed } \\
\text { diarrhoea }\end{array}$ \\
\hline Szymanski $2008^{17}$ & $\begin{array}{l}78 \text { children aged } 5 \text { months to } 16 \text { years with } \\
\text { respiratory tract infections, inpatients and } \\
\text { outpatients }\end{array}$ & $\begin{array}{l}\text { B longum, } L \text { rhamnosus, and } L \text { plantarum, } \\
\text { twice daily at } 10^{8}\end{array}$ & $\begin{array}{l}0.50(95 \% \mathrm{Cl} 0.06 \text { to } 3.50) ; 2.5 \% \text { intervention } \\
\text { and } 5.3 \% \text { placebo treated children developed } \\
\text { diarrhoea }\end{array}$ \\
\hline
\end{tabular}

